International Journal of Linguistics, Literature and Translation (IJLLT)

ISSN: 2617-0299 (Online); ISSN: 2708-0099 (Print)

DOI: $10.32996 / \mathrm{ijllt}$

Website: https://al-kindipublisher.com/index.php/ijllt

\title{
Representing the Zeitgeist: A Foucauldian Reading of Jack Kerouac's The Subterraneans
}

Fazel Asadi Amjad ${ }^{1}$, Kamran Ahmadgoli ${ }^{2}$ and Saman Sadr ${ }^{3}$

${ }^{1}$ Full Professor, English Department, Kharazmi University, Iran

${ }^{2}$ Associate Professor, English Department, Kharazmi University, Iran

${ }^{3}$ PhD Candidate, English Department, Kharazmi University, Iran

Corresponding Author: Saman Sadr, E-mail: saman.sadr70@gmail.com

\section{ARTICLE INFO ABSTRACT}

Received: September 01, 2020

Accepted: October 16, 2020

Volume: 3

Issue: 10

DOI: $10.32996 /$ ijllt.2020.3.10.17

\section{KEYWORDS}

Michel Foucault, Jack Kerouac, Institution, Power, Surveillance, Unfreedom, disillusionment
This study is an attempt at reading Jack Kerouac's "The Subterraneans" in the light of the theory of Michel Foucault. "The Subterraneans", written in 1958, grapples with the life of Leo, the alter ego of Jack Kerouac himself. The actions and interactions of its main characters, Leo Percepied and Mardou Fox, are observed and analyzed, focusing on the political philosophy of Foucault, specifically his conceptions of power, power relations, institutions, and surveillance to shed light on the ideas of Kerouac, the spokesperson of the Beat Generation. Kerouac's novel represents the spirit of the age of a people who sought change, difference, and disobedience; the main characters are antiheroes who challenge their prisonlike structure of the society. In contrast, the government has the upper hand by means of its distinct and overlapping institutions that not only neutralize such acts or resistances but make normal and ordinary those individuals who were themselves the promoters and examples of abnormality. Jack Kerouac's "The Subterraneans" is characterized by unfreedom, obedience, unthinking men, individuals without individuality, and disillusionment.

\section{Introduction and Theoretical Framework}

While institutions are generally believed to exist so as to serve the needs of individuals in the society, Foucault counters the idea, arguing that individuals need to distrust institutions and the practices they perform to people. The modern society that the modern man inhabits is replete with institutions that forge individuals who serve it and help it get going. Institutions create norms to force individuals to follow and observe them which, in return, make them act and behave as they are conditioned; in other words, the social control which has been something ordinary in all societies gives place to a new form of control which is institutions and which is both created by and for them to perform disciplinary orders.

By extension, Foucault (1995) evinces his pessimism regarding the innumerable institutions that surround and circulate inside the society as he thinks of their functions to be creating meek individuals, as well as a homogenized society:

It was a complex function since it linked the absolute power of the monarch to the lowest levels of power disseminated in society; since, between these different, enclosed institutions of discipline (workshops, armies, schools), it extended an intermediary network, acting where they could not intervene, disciplining the non-disciplinary spaces; but it filled in the gaps, linked them together, guaranteed with its armed force an interstitial discipline and a meta-discipline. 'By means of a wise police, the sovereign accustoms the people to order and obedience. (p. 215)

K C AL-KINDI CENTER R D FOR RESEARCH AND D DEVELOPMENT Your gateway to world-class research
Published by Al-KindiCenter for Research and Development. Copyright (c) the author(s). This is an open access article under CC BY license (https://creativecommons.org/licenses/by/4.0/) 
The control that the state exercises on individuals depends utterly on institutions that are built-in sites in the structure of power. Modern states forge a kind of matrix, a space which institution create by their prison-and-net-like structure that limits all acts that individuals do in their lives. However, what makes modern power-exercise different from the former way of wielding power before the modern age is its attempt at making the control of individuals done by invisible institutions, though it guarantees the invariable presence and pressure in the entire society. The institutions overlap and connect with other institutions, creating a matrix that makes being outside institutions virtually impossible; this phenomenon, however, demonstrates that, in modern societies, not only institutions and the matrix they create bring about a disciplinary structure, but also the whole structure becomes disciplinary and prisonlike. All kinds of the institutions that make up matrices including prisons, courts, asylums, schools, and hospitals are conducive to institutionalized human beings inhabiting institutionalized societies whose every aspect of life inducing health, security, penalties, and education become disciplinary. Foucault (1995) in Discipline and Punish writes:

But, conversely, if the judges accept ever more reluctantly to condemn for the sake of condemning, the activity of judging has increased precisely to the extent that the normalizing power has spread. Born along by the omnipresence of the mechanisms of discipline, basing itself on all the carceral apparatuses, it has become one of the major functions of our society. The judges of normality are present everywhere. We are in the society of the teacher-judge, the doctor-judge, the educator-judge, the 'social worker' -judge; it is on them that the universal reign of the normative is based; and each individual, wherever he may find himself, subjects to it his body, his gestures, his behaviour, his aptitudes, his achievements. The carceral network, in its compact or disseminated forms, with its systems of insertion, distribution, surveillance, observation, has been the greatest support, in modern society, of the normalizing power. (p. 304)

Foucault maintains that these institutions were the real cause of all control and surveillance in prisonlike slots; however, there have always been individuals who have been able to go out of the scope and control of institutions which has again led to the emergence of other institutions that have sought to leave no space unchecked. All the ever-existing situations and the ones which have appeared over modern times in modern societies have checked and double-checked the normality, subjection, and meekness of the institutionalized modern man. As a way of example, Foucault touches upon the question of normality. For Foucault, normality has been invariably checked in institutions from medicine to psychiatry, from school to army, and from churches to even factories which have formed what Foucault calls 'carceral archipelago'; despite being sometimes diametrically opposite and even hostile, these institutions all act in accordance to take individuality away from their subjects, to subjug ate them, and to unman them by the circuits of institutions that they have forged:

The specific, institutional supports of these methods have proliferated since the founding of the small school at Mettray; their apparatuses have increased in quantity and scope; their auxiliary services have increased, with hospitals, schools, public administrations and private enterprises; their agents have proliferated in number, in power, in technical qualification; the technicians of indiscipline have founded a family. In the normalization of the power of normalization, in the arrangement of a power-knowledge over individuals, Mettray and its school marked a new era. (p. 296)

Moreover, Foucault speaks of the maturity of disciplinary control which culminates in functioning of all institutions in tandem in a way that there will be left no place for the individual to act which is outside the purview of those normalizing institutions. This kind of maturity of institutions leads to a kind of governmentality of individuals by the state that works at the level of the unconscious of people who are being controlled as the mechanism and strategies adopted by institutions have become invisible and permanent, as well as inculcated and internalized by the subjects themselves.

When conceptualizing about power and power relations, Foucault, initially, negates the idea that power is the ability of the powerful people to force the powerless ones in terms of making their wants come true; in other words, denying the idea that power is something at the hands of the powerful people which can be used against the powerless who are deprived of it. As Foucault (1980) maintains in Power/Knowledge:

Power must by analyzed as something which circulates, or rather as something which only functions in the form of a chain. It is never localized here or there, never in anybody's hands, never appropriated as a commodity or piece of wealth. Power is employed and exercised through a net-like organization. And not only do individuals circulate between its threads; they are always in the position of simultaneously 
undergoing and exercising this power. They are not only its inert or consenting target; they are always also the elements of its articulation. In other words, individuals are the vehicles of power, not its points of application. (p. 98)

For Foucault, power is best understood when it is seen as a verb which does and performs a strategy rather than a noun which refers to having something at one's disposal. Furthermore, power is not merely a reciprocal relationship between those who have power and those who are deprived of it; rather, it is a kind of 'chain' that permeates the whole wider society in which all individuals, regardless of their position and rank, are held accountable and influential. Foucault also insists that individuals must not be seen merely as those who receive power; to the contrary, he maintains that individuals are slots and sites where power is both wielded and resisted. Subsequently, Foucault adds one new dimension to the way power must be analyzed which the inclusion of the individual as one important factor in power relations from being a power dupe to being a power-informing and power-challenging force. Here is a reconceptualization of power by Foucault (1988):

I am not referring to Power with a capital $\mathrm{P}$, dominating and imposing its rationality upon the totality of the social body. In fact, there are power relations. They are multiple; they have different forms, they can be in play in family relations, or within an institution, or an administration - or between a dominating and a dominated class. ... it is a field of analysis and not at all a reference to any unique instance. [Furthermore] in studying these power relations, I in no way construct a theory of power. But I wish to know how the reflectivity of the subject and the discourse of truth are linked - "How can the subject tell the truth about itself?" - and I think that relations of power exerting themselves upon one another constitute one of the determining elements in this relations I am trying to analyze. (Michel Foucault: Politics, Philosophy, Culture, p. 38)

\section{Discussion}

Mardou talks about her situation before she meets the subterraneans and the way she describes her situation seems to clearly represent what all people were doing at the time:

I was just an innocent chick when I met them, independent and like well not happy or anything but feeling that I had something to do, I wanted to go to night school, I had several jobs at my trade, binding in Olstad's and small places down around Harrison, the art teacher the old gal at school was saying I could become a great sculptress and I was living with various roommates and buying clothes and making it. (Kerouac, 1958, p. 11)

The first important note is that she calls herself an innocent chick; by saying she was an innocent chick, she implies that she is a meek person in the society who is ready to do anything she is told by the government; that is why she singles out going to night school as the significant thing that can give her life meaning. She also argues that she could choose among several jobs that were available to her and that she could even become a professional sculptress. That fact is that, by being shown so many options that she can choose in her life, she will be able to lead the life she desires which is, in contrast, the life the government desires for her.

\subsection{Work Places as Institutions}

With the opening of the novel, Leo Percepied has just left his work as a messman in a ship in New York. Before they settle their trip to Japan, Leo had an argument with the steward:

I'd just come off a ship in New York, paid off before the trip to Kobe Japan because of trouble with the steward and my inability to be gracious and in fact human and like an ordinary guy while performing my chores as saloon messman (and you must admit now I'm sticking to the facts), a thing typical of me, I would treat the first engineer and the other officers with backwards-falling politeness, it finally drove them angry, they wanted me to say something, maybe gruff, in the morning, while setting their coffee down and instead of which silently on crepefeet I rushed to do their bidding and never cracked a smile or if so a sick one, a superior one. (p. 8)

The working place is one of the most influential sites that the obedience of the people in the society is guaranteed. Leo argues that he behaved and talked utterly politely towards all the staff and the officers he used to work for. Despite the fact that Leo 
argues that he has become crazy at their commands and has left the place, Leo has experienced being their inferior, messman, and yes-man for a long time which has had a profound effect on the way he finds himself in the society. While Leo contends that he has been able to protest to how they have behaved and what they have told him, he does not deny that he has internalized the way people, and in his case messmen and workers, must behave.

The first thing that Leo imagines is his being a half-breed hobo who is hitchhiking throughout America who seems to be facing misfortunes. Later, he sees him as a picker who works in the cotton fields:

I kept imagining that Cherokee-halfbreed hobo father of hers lying bellydown on a flatcar with the wind furling back his rags and black hat, his brown sad face facing all that land and desolation. - At other moments I imagined him instead working as a picker around Indio and on a hot night he's sitting on a chair on the sidewalk among the joking shirtsleeved men, and he spits and they say, "Hey Hawk Taw, tell us that story agin about the time you stole a taxicab and drove it clear to Manitoba, Canada-d'jever hear him tell that one, Cy?"-I saw the vision of her father, he's standing straight up, proudly, handsome, in the bleak dim red light of America on a corner, nobody knows his name, nobody cares- (p. 21)

Leo's description of "nobody knows his name, nobody cares" is much more profound than it seems; in Foucault's terms, the most important thing that states are following in institutionalizing and, thus, normalizing, individuals. What the American government does is the same, which is making people ignore the names, the identities, and the differences. Being a hobo makes individuals always be ready to be confronted by the law, police, and their satellite institutions that seek their normality. Hobos are dominantly monitored by various institutions that are highly suggestive in terms of the restricting the freedom of individuals. On the other hand, working also puts individuals in a structure that makes the work itself secondary and the institutionalizing of the individuals its primary goal; that is; the disciplinary structure of the working system forges individuals who are both docile and capable of productive work and endeavor.

Furthermore, he speaks of the lives of Indians who have become modern slaves to the capitalist system of America while they have been the real owners of the fields in America originally. He also mentions African Americans and even Armenians as the people who have been utterly suppressed by working in such a system. Most importantly, on the other hand, is the situation of Leo himself as he has worked for the same system for a long time. Leo has worked on the same land that Mexicans, Indians, African Americans, and many others have worked for the capitalist system; consequently, it has been such a system that has created individuals who are devoid of individuality and they are, in effect, turned into subjects rather than individuals. Leo himself, who has been regarded as the spokesperson for the Beat Generation that had developed, seems rather as a meek person who finds his full life, liberty, and distinctiveness in sleeping with Mardou.

Almost all subterraneans go to work which is a sign of institutionalization. Adam Moorad, the name Kerouac uses in the novel of Alan Ginsberg, is one of the most significant characters of Beat Generation; however, the American system that uses work places so as to produce more and also normalize more has been able to make Adam work for sites where he is sure are transforming him into simpletons: "Adam rising to go to work, I too, washing, mumbling talk, when the phone rang and it was Mardou, who was going to her therapist, but needed a dime for the bus, living around the corner" (p. 20).

Even Leo, who has been avoiding working for a long time as he recognizes the detrimental effects of working for a system that aims at constricting the freedom of individuals, falls for the trap where he finds working as a fulfillment of one duty in the society:

the noise in Heavenly Lane sneaking in through the gray window, a gray doomsday in August so I feel like leaving at once to get "back to my work" the chimera of not the chimera but the orderly advancing sense of work and duty which I had worked up and developed at home (in South City) humble as it is, the comforts there too, the solitude which I wanted and now can't stand. - I got up and began to dress, apologize, she lay like a little mummy in the sheet and cast the serious brown eyes on me ... Aztecan. - "But why do you have to rush off so fast, as though almost hysterical or worried?" - "Well I do I have work to do and I have to straighten out-hangover-" and she barely awake, so I sneak out with a few words in fact when she lapses almost into sleep and I don't see her again for a few days. (p. 20) 


\subsection{Police}

In a similar case, when Mardou and Jack Steen are having a small altercation in which Mardou became furious, the first thing that happened to them was the presence of the police as the arbiter of what should be the case:

"Like Julien finally won at wrists but he really furiously had to put me down to do it and hurt me and was really upset" (gleeful little shniffle thru the little out-teeth)-so there she'd been fighting it out with Jack Steen and really almost licking him but he was furious and neighbors downstairs called cops who came and had to be explained to-"dancing." (p. 27)

While no one involved in the altercation called the police and it was the neighbors who called them, the police intervened and they had to find a reason to justify that they were not doing something illegal. In a way, the police intervene in the lives of the individuals on a daily basis even if they are unwanted. In justifying why they were making some noise, Mardou and Steen has to say that they were dancing.

In a memorable scene in the novel, Leo talks about a night when Mardou arrived at home after spending some nights with a man he had loved. When she arrived home, her family berated her and she starts going into the yard of the house. As for always, the police force was present at the scene where many people including Mexicans, African Americans, and most importantly whores:

In the ramshackle wood upstairs of their cottage near Seventh and Pine the railroad sooty wood and gargoyle porches like tinder in the sham scrapple slums, the yard nothing but a lot with broken rocks and black wood showing where hoboes Tokay'd last night before moving off across the meatpacking yard to the Mainline rail Tracy-bound thru vast endless impossible Brooklyn-Oakland full of telephone poles and crap and on Saturday nights the wild Negro bars full of whores and the Mexicans Ya-Yaaing in their own saloons and the cop car cruising the long sad avenue riddled with drinkers and the glitter of broken bottles. (p. 33)

As this example illustrates, the police does not undertake grappling with any of the real problems that the society is involved with and, thus, they do not undertake freeing whores, helping African Americans find their place and status in the American system, and the like. The real function of the police and its agents is rather making people as meek and in control as possible without allowing them to understand their real self.

At home, Mardou is the youngest girl; she is alcoholic and used to frequent some specific streets when she was arrested, being charged as wrong. However, she is simply kept in prison for some time and is then transferred to another institution, the institution of hospital. After trying to institutionalize her by the police force in terms of making her not to do any wrong anymore, she is sent to hospital to make sure that there is nothing wrong with mind; in other words, a survey into the state of behavior has given way to another survey into her mental circumstances, both of which go out of their ways to help normalize her and transform her into an ordinary person:

Who was alcoholic and made the wild street and got arrested regularly by the vice squad, some nameless horrible yawning wrong, "She smokes dope, she hangs out with all those queer guys with beards in the City." - They called the police and Mardou was taken to the hospital-realizing now, "God, I saw how awful what was really happening and about to happen to me and man I pulled out of it fast, and talked sanely with everyone possible and did everything right, they let me out in 48 hours - the other women were with me, we'd look out the windows and the things they said, they made me see the preciousness of really being out of those damn bathrobes and out of there and out on the street, the sun, we could see ships, out and FREE man to roam around, how great it really is and how we never appreciate it all glum inside our worries and skins, like fools really, or blind spoiled detestable children pouting because ... they can't get ... all ... the ... candy ... they want, so I talked to the doctors and told them-." (p. 34)

While in prison, Mardou is taught to believe that her life before she was arrested by the police and then taken to hospital was simply wrongdoings; she even thanks the different institutions that have helped her find her place in society which is a hospital. While there, she believes that it is the only time she is talking with others in a reasonable way and sanely. In the hospital, Mardou, along with other imprisoned there, looks out of windows of the hospital and on seeing people living normally, they come to the conclusion that the real life is the life of all the people who live correctly, normally, ordinarily, and according to 
the rules and norms of the society that is also promoted by the same hospital they are living now. She finds them as "FREE" men who walk around without any worries about anything except being free in the way they are allowed to be free, like fools, and like children.

Leo has been to jail several times in the novel and Mardou has been arrested by the police and she has also become imprisoned in a hospital and both of them, as the novel opens, have lost their almost innate ability to act abnormally. The different institutions, most importantly the institutions of prison and hospital have transformed individuals into subjects who are meek and docile with a significant capability of being submissive and obedient.

\subsection{School and Family}

One night when Leo is left alone by Mardou, John Golz comes to her apartment and seeing Leo alone, he starts talking about literature. As John Golz knows that Leo is a successful writer, he starts by saying that selectivity is an important concept in literature. At this moment, Leo starts criticizing the academic institutes that have merely taught students to namedrop and regurgitate whatever they been inculcated. He believes that literature is something utterly different from what they are told about in schools which seeks to ground all learning about literature in a set of norms and standards that are definition of literature by the government and not by those who are creative writers:

That night, I was at her place waiting, reading, young John Golz came in to borrow cigarettes and seeing I was alone wanted to talk literature-"Well I believe that the most important thing is selectivity," and I blew up and said "Ah don't give me all that high school stuff I've heard it and heard it long before you were born almost for krissakes and really now, say something interesting and new about writing" - putting him down, sullen, for reasons mainly of irritation and because he seemed harmless and therefore could be counted on to be safe to yell at, which he was - putting him down, her friend, was not nice-no, the world's no fit place for this kind of activity, and what we gonna do, and where? when? wha wha wha, the baby bawls in the midnight boom. (p. 66)

Mardou had not had a family of her own, no father, mother or brothers or sisters and, thus, she was raised in her uncle's house. The institution of family becomes the first site that starts the trajectory that ends in that of mental hospital, police, and work places. When she was just a kid, she had to do difficult and boring chores what were hard for her to perform and that is the first place that her normalization and internalizing arbitrary rules and norms forms her subjectivity:

she was forced to wash dishes for her tyrannical uncle's family and all the time on top of that forced to go out in alley in dark night with garbage pan every night same time where she was convinced the same ghost lurked for her- doubts, doubts-which I have not now in the luxury of time-past. (p. 40)

All through the novel, Leo is discouraged to act abnormally due to the fact that his mother is waiting for him with his love; his mother is there to defuse all his actions to get freedom and start an abnormal life and that is why most of his friends, boys and girls alike, are secondary to him. He cannot marry and he cannot have close relationships with any of the men like Leroy who has been his closest friend in On the Road. Even when Leo is with Mardou, he always dreams of going back to his mother's house as she is the one who irons his clothes, makes him food, and teaches him how to live, which is a redirecting of what she is taught to be a "good" citizen for the government:

Well you've done a lot of things for her," and Adam Moorad (whom my mother considered mad and evil) too had once said "You've really done a lot for her, Leo, forget her for a while, you've got your own life to live," which is exactly what my mother always was telling me in the dark of the South San Francisco night when we relaxed with Tom Collinses under the moon and neighbors would join us, "You have your own life to live, I won't interfere, Ti Leo, with anything you want to do, you decide, of course it will be all right with me," me sitting there goopy realizing it's all myself, a big subjective phantasy that my mother really needs me and would die if I weren't around. (p. 43-44)

When Adam and Leo had an argument after they had used a pushcart and taken it back to Adam's apartment, Leo is frustrated at Adam's berating him and gives his apartment keys back to him. However, the key chain has two sets of keys, one belonging to Adam and the other belonging to his mother. It takes a short time to separate and take out the keys and when has only his 
mother's keys, he feels much more comfortable; the keys become symbols of his limitations at the hands of his mother who is the most powerful person in his life who is institutionalizing him along many other satellite institutions:

But seeing suddenly not in the face of the moon but somewhere in the sky as I looked up and hoped to figure, the face of my mother-remembering it in fact from a haunted nap just after supper that same restless unable-to-stay-ina- chair or on-earth day-just as I woke to some Arthur Godfrey program on the TV, I saw bending over me the visage of my mother, with impenetrable eyes and moveless lips and round cheekbones and glasses that glinted and hid the major part of her expression which at first I thought was a vision of horror that I might shudder at, but it didn't make me shudder. (p. 88)

Leo's mother becomes a police officer, the company manager, the doctor at the mental hospital, and all other agents in institutions that bring about doubts, horrors, fears, a sense of being continuously watched and penalized at the sight of any abnormality; however, the same things, techniques, and punishments are applied in the institution of the family as a private space that aims at internalizing the ideology and way of life promoted by the government:

Wondering about it on the walk and suddenly now in the railyards weeping for my lost Mardou and so stupidly because l'd decided to throw her away myself, it had been a vision of my mother's love for me - that expressionless and expressionless-because-so-profound face bending over me in the vision of my sleep, and with lips not so pressed together as enduring and as if to say, "Poor Little Leo, poor Little Leo, you suffer, men suffer so, you're all alone in the world I'll take care of you, I would very much like to take care of you all your days my angel."-My mother an angel too-the tears welled up in my eyes, something broke, I cracked. (p. 88)

The institution of family, in the form of a domineering mother, makes Leo envisage a world of danger from all people and things in the world, misleading him to inculcate the idea that they are only institutions that help individuals have normal lives by which they can live freely and happily.

\section{Conclusion}

The study sought to represent the real workings of power and power relations in the real context of the United States at the time when Kerouac wrote his masterpieces and the researcher tried to provide a genuine and firsthand representation of the political, social, cultural, and historical context.

Almost never pointing to the world outside America, Kerouac highlights the life of individuals in the years after the Second World War caught up and imprisoned in numerous situations which represent the master ideology of the government. Mardou and Leo have struggles against the norm inducing institutions all their lives; Mardou was raised by strict relatives who have made her do according to their wishes. She is then sent to school and later to work for different bosses and managers who add to her being an institutionalized person. On the other hand, Leo experiences being the son of a police officer, a company manager, and the doctor of a mental hospital, all of which are occupations that need the staff and the participants to be institutionalized, promote institutionalization, and make other stick to their norms and standards.

Foucault's ideas, notions, and political theory that have been adopted in this research could be dispensed with and other students who want to reexamine the same works of Jack Kerouac can resort to other political philosophers such as Louis Althusser, Pierre Bourdieu, Slavoj Zizek, Alain Badiou, Antonia Negri, Pierre Macherey, Giorgio Agamben, and the like to retest their theories in proving Foucault's ideas right or wrong. The relationship between individuals and governments is the main emphasis of these theorists and applying their ideas would assist readers to have a better understanding of the period of time focused in the novel.

\section{References}

[1] Kerouac, J. (1958). The Subterraneans. Grove Press.

[2] Foucault, M. (1995). Discipline and Punish: The Birth of the Prison. $2^{\text {nd }}$ ed. Vintage.

[3] Foucault, M. (1988). Politics, Philosophy, Culture: Interviews and Other Writings. Routledge.

[4] Foucault, M. (1980). Power-Knowledge. Pantheon Books. 